\title{
Comparative Study of Various Next Generation Network- Business Process Frameworks
}

\author{
Priya R. L \\ Computer Engineering Department, \\ VESIT, Mumbai, India
}

\author{
Nupur Giri, Ph.D \\ Computer Engineering Department, \\ VESIT, Mumbai, India
}

\begin{abstract}
The paper discuss the impact of different process frameworks along the various key parameters that synthesizes views from areas such as information systems development, enterprise modeling and work flow management. The idea behind this comparison study of Next Generation Network (NGN) Business Process Framework is to help practitioners to identify different views one should consider whenever applying a Business Process Framework implementation project.
\end{abstract}

\section{Keywords}

NGN, eTOM

\section{INTRODUCTION}

The growth in telecommunication industry in technology, forced the necessity to shape up the existing business models. A business process [7, 15] can be defined as a flow of business activities. Nowadays, the Business Process Framework (BPF) is a key survival factor for various companies such as telecommunication, information technology, and manufacturing companies since effective and efficient BPF can reduce operations cost and can achieve better Quality of Service(QoS).

\section{LITERATURE SURVEY}

As defined in International Telecommunication Union(ITU) $[1,2,11]$, Next Generation Network (NGN) allows for the creation and deployment of a new service and network architecture. This architecture defines the main business requirements in Information and Communication Technologies(ICT) area. The operational activities of an enterprise can be analyzed and integrated through its business processes. Here comes the relevance of Business Process Modeling (BPM).Business process framework are different within each process since different activities are needed to complete the process functions.

\section{COMPARISON OF (NGN) BUSINESS PROCESS FRAMEWORKS (BPF)}

eTOM, ITIL, Zachman, TOGAF and COBIT are widely used best practices in IT service operations and service managements. And here a comparison from different perspectives may help in explaining their purposes, exploitations, results and way of combining them in project executions.

\section{1 eTOM (Enhanced Telecom Operations Map ) \\ The eTOM $[4,5,6]$ framework can be viewed as covering three major business process areas such as Strategy, Infrastructure and Product (SIP), Operations and Enterprise Management (EM). SIP deals with planning and lifecycle management (associated with development and delivery of the product), Operations deals with core of operational management and EM focuses on corporate / business support management.}

\subsection{ITIL (Information Technology Infrastructure Library)}

In ITIL [9] , the first three phases such as Service Strategy, Service Design and Service Transition are primarily concerned with bringing new or improved services to the service catalog. Service Operation and Continual Service Improvement are concerned with service delivery and optimization of current services.

\subsection{Zachman}

Zachman framework [10] helps to define a logical structure for the descriptive representations of any complex object. It does not prescribed to any particular method, representation technique or automated tool.

\subsection{TOGAF(The Open Group Architecture Framework)}

The TOGAF [3] explains four kinds of "architecture" such as: Business, Data, Application and Technology architectures, that are commonly accepted as subsets of an overall Enterprise Architecture.

\subsection{COBIT(The Control Objectives for Information Technology)}

COBIT [9] is an IT Governance and Control framework that focuses on all IT related processes to ensure good governance of an enterprise.

\section{NGN BPF COMPARISON}

The following table 1 illustrates the comparison of various NGN Business Process Frameworks used in any telecommunication industry. Various key attributes are used to discuss the impacts of each business process frameworks. 
Table 1 : Comparison of NGN Business Process Frameworks

\begin{tabular}{|c|c|c|c|c|c|}
\hline $\begin{array}{c}\text { Key } \\
\text { Features }\end{array}$ & eTOM & ITIL & Zachman & TOGAF & COBIT \\
\hline Adoption & $\begin{array}{c}\text { ITU } \\
\text { (International } \\
\text { Telecommunicati } \\
\text { on Union) }\end{array}$ & $\begin{array}{l}\text { Adapted with good } \\
\text { practices such as } \\
\text { CoBIT, TOGAF, Siz } \\
\text { Sigma and so on. }\end{array}$ & $\begin{array}{l}\text { Zachman } \\
\text { International } \\
\text { standard. }\end{array}$ & The Open Group & $\begin{array}{l}\text { Global Standard for } \\
\text { IT governance }\end{array}$ \\
\hline Definition & $\begin{array}{c}\text { eTOM comprises } \\
\text { hierarchical } \\
\text { levels of } \\
\text { enterprise } \\
\text { processes with } \\
\text { priority } \\
\text { significance. }\end{array}$ & $\begin{array}{l}\text { ITIL is a service } \\
\text { design framework } \\
\text { that connects } \\
\text { technology, people, } \\
\text { and enterprise } \\
\text { processes inorder to } \\
\text { optimize current } \\
\text { services. }\end{array}$ & $\begin{array}{l}\text { Zachman is a } \\
\text { taxonomy structure } \\
\text { to NGOSS. }\end{array}$ & $\begin{array}{l}\text { TOGAF is an } \\
\text { architecture } \\
\text { framework to design, } \\
\text { evaluate, and build the } \\
\text { right architecture for } \\
\text { organization. }\end{array}$ & $\begin{array}{l}\text { COBIT is a Control } \\
\text { Framework providing } \\
\text { tools which measures } \\
\text { the efficiency of IT } \\
\text { processes and the } \\
\text { efficiency of IT } \\
\text { alignment with } \\
\text { business. }\end{array}$ \\
\hline Objective & $\begin{array}{l}\text { eTOM comprise } \\
\text { as an assembly } \\
\text { of information } \\
\text { management } \\
\text { systems. } \\
\end{array}$ & $\begin{array}{l}\text { ITIL provides well } \\
\text { defined practice for } \\
\text { single information } \\
\text { management system. }\end{array}$ & $\begin{array}{l}\text { Zachman provides a } \\
\text { holistic approach to } \\
\text { architecting } \\
\text { systems. }\end{array}$ & $\begin{array}{l}\text { TOGAF provides data } \\
\text { dictionary for all } \\
\text { architectural assets of } \\
\text { an enterprise and IT } \\
\text { industry. } \\
\end{array}$ & $\begin{array}{l}\text { COBIT provides } \\
\text { conformance and } \\
\text { performance of IT } \\
\text { Processes. }\end{array}$ \\
\hline $\begin{array}{c}\text { Key } \\
\text { Dimensions }\end{array}$ & $\begin{array}{l}\text { eTOM follows } \\
\text { two-dimensional } \\
\text { approach. First } \\
\text { dimension covers } \\
\text { functional view } \\
\text { points and second } \\
\text { dimension covers } \\
\text { business view } \\
\text { points. }\end{array}$ & $\begin{array}{c}\text { ITIL is of one- } \\
\text { dimensional } \\
\text { approach comprise } \\
\text { with five phases of } \\
\text { service management. }\end{array}$ & $\begin{array}{l}\text { It introduces a two- } \\
\text { dimensional } \\
\text { approach. First } \\
\text { approach, based on } \\
\text { the stakeholder's } \\
\text { perspective at a } \\
\text { generic level. } \\
\text { Second dimension } \\
\text { provides model } \\
\text { view at a specific } \\
\text { detailed level. }\end{array}$ & $\begin{array}{c}\text { It follows one } \\
\text { dimensional cyclic } \\
\text { approach consists of, } \\
\text { various key phases to } \\
\text { define IT } \\
\text { management. }\end{array}$ & $\begin{array}{c}\text { COBIT uses one } \\
\text { dimensional iterative } \\
\text { approach, comprising } \\
\text { the phases of IT } \\
\text { governance. }\end{array}$ \\
\hline $\begin{array}{l}\text { Process } \\
\text { Layout }\end{array}$ & $\begin{array}{c}\text { eTOM gives } \\
\text { horizontal view } \\
\text { of various } \\
\text { domains, and all } \\
\text { operational } \\
\text { activities are } \\
\text { subjected in } \\
\text { vertical view. }\end{array}$ & $\begin{array}{l}\text { ITIL processes } \\
\text { comply with the time } \\
\text { order of service } \\
\text { activities in an } \\
\text { enterprise project. }\end{array}$ & $\begin{array}{c}\text { The Zachman } \\
\text { Framework } \\
\text { provides six } \\
\text { different } \\
\text { transformations(Sta } \\
\text { keholder view) of } \\
\text { an abstract idea } \\
\text { from six different } \\
\text { perspectives (Model } \\
\text { View). }\end{array}$ & $\begin{array}{l}\text { TOGAF follows the } \\
\text { process of building } \\
\text { block definition as a } \\
\text { reference architecture } \\
\text { Development in an IT } \\
\text { user enterprises. }\end{array}$ & $\begin{array}{l}\text { The process model } \\
\text { subdivides IT into } \\
\text { four domains and } \\
\text { govern IT process of } \\
\text { an enterprise. }\end{array}$ \\
\hline Uses & $\begin{array}{c}\text { Provides a } \\
\text { standard structure } \\
\text { for business } \\
\text { processes and } \\
\text { their building } \\
\text { blocks. } \\
\end{array}$ & $\begin{array}{l}\text { ITIL is meant to } \\
\text { improve IT processes } \\
\text { and implementations. }\end{array}$ & $\begin{array}{l}\text { To create a } \\
\text { competitive } \\
\text { enterprise } \\
\text { framework. }\end{array}$ & $\begin{array}{l}\text { To build genuinely } \\
\text { open systems-based } \\
\text { solutions to business } \\
\text { needs. }\end{array}$ & $\begin{array}{c}\text { It provides } \\
\text { Continuous } \\
\text { improvement in } \\
\text { performance and staff } \\
\text { productivity. }\end{array}$ \\
\hline $\begin{array}{c}\text { Target } \\
\text { Audience }\end{array}$ & $\begin{array}{c}\text { eTOM focuses on } \\
\text { telecom } \\
\text { companies and } \\
\text { service providers. }\end{array}$ & $\begin{array}{l}\text { ITIL is focused on IT } \\
\text { organizations and the } \\
\text { provisioning of IT } \\
\text { services. }\end{array}$ & $\begin{array}{l}\text { It is designed for } \\
\text { enterprise } \\
\text { professionals } \\
\text { including non- } \\
\text { information } \\
\text { disciplines as well } \\
\text { as information } \\
\text { disciplines. }\end{array}$ & $\begin{array}{l}\text { Any mission-critical } \\
\text { business applications, } \\
\text { using open systems } \\
\text { building blocks. }\end{array}$ & $\begin{array}{l}\text { Management, Users } \\
\text { and Auditors in SOX. }\end{array}$ \\
\hline Applications & $\begin{array}{l}\text { ITU, Vodafone, } \\
\text { Verizon, OSS } \\
\text { through Java } \\
\text { Initiative, } \\
\text { Amdocs and so } \\
\text { on. }\end{array}$ & $\begin{array}{c}\text { Financial services } \\
\text { organizations such as } \\
\text { Citi, Bank of } \\
\text { America, Large } \\
\text { technology } \\
\text { companies such as } \\
\text { Microsoft, HP, } \\
\text { Fujitsu, IBM etc. }\end{array}$ & $\begin{array}{l}\text { Applied both in } \\
\text { commercial } \\
\text { companies and in } \\
\text { government } \\
\text { agencies. Used as a } \\
\text { reference model for } \\
\text { other enterprise } \\
\text { architectures such as } \\
\text { DoD, TOGAF, EAP } \\
\text { etc. }\end{array}$ & $\begin{array}{l}\text { The UK Department } \\
\text { of Social Security } \\
\text { (DSS), Litton PRC } \\
\text { (US), NATO } \\
\text { (Belgium) and so on. }\end{array}$ & $\begin{array}{l}\text { Areas such as privacy } \\
\text { and financial } \\
\text { reporting (e.g., the US } \\
\text { Sarbanes-Oxley Act) } \\
\text { and in specific sectors } \\
\text { such as finance, } \\
\text { pharmaceutical and } \\
\text { healthcare. }\end{array}$ \\
\hline
\end{tabular}




\section{CASE STUDY : ECORE DESIGN}

As defined in ITU-T Y.2012 eTOM business process areas such as Strategy, Infrastructure and Product (SIP), Operations and Enterprise Management (EM) are represented in a hierarchical fashion. Within the TM Forum Business Process Framework, eTOM Level 0 to 3 already defined as a standard in generic way. However, the figure 2 depicts Operation processes of eTOM in level 2 decomposition and explains end-to-end process flow for Order Fulfillment in a cellular domain. The operation process shows major business components and flow of Service Fulfillment, Assurance and Billing. Fulfillment, Assurance and Billing (FAB) or Vertical processes is the heart processes and describes business view points. Fulfillment processes are shown in solid rectangle boxes, Assurance processes are shown in dotted rectangle boxes and Billing processes are shown in dashed rectangle boxes. The triggers are conditions marked with arrows between processes and the large red arrows are external triggers from this flow. The four Swim Lanes (SL) or horizontal processes such as Customer Relationship Management (CRM), Service Management and Operations (SMO), Resource Management and Operations (RMO) and Supplier/ Partner Relationship Management (S/PRM) represent functional view points in eTOM framework.

\subsection{Order Fulfillment Process in a Cellular Network using eTOM:}

First layer of SL [16], CRM processes such as Selling, Order Handling, Retention and Loyalty, etc. considers the fundamental knowledge of customer needs and includes all tasks necessary for acquisition, enhancement and retention of a customer relationship. It is about customer service and support, retention management, up-selling and direct marketing to customers, represent the billing function at the customer level and the need to assure revenue. eTOM integrates Customer Interface Management (CIM) for FAB across all the CRM processes. Next, SMO process like Service Configuration and Activation mainly focuses on the knowledge of services (Access, Connectivity, Content etc.) and includes activities (service delivery and management, maintain service quality, service cost etc.) required for the management and operations of communications and information services required by a customer. RMO process such as Resource Provisioning maintains knowledge of resources (application, computing and network infrastructures) and manage all resources, (e.g. IT Systems, Servers, Routers etc.) utilized to deliver and support services required by a customer or within the enterprise. Finally, S/PRM processes such as S/P Buying, S/P Purchase Order Management, S/P Settlement Billing Management supports both the customer instance processes of $\mathrm{FAB}$ and functional operations processes. It include issuing purchase orders and tracking them through to delivering, handling problems, validating billing and authorizing payment, as well as quality management of suppliers and partners. 


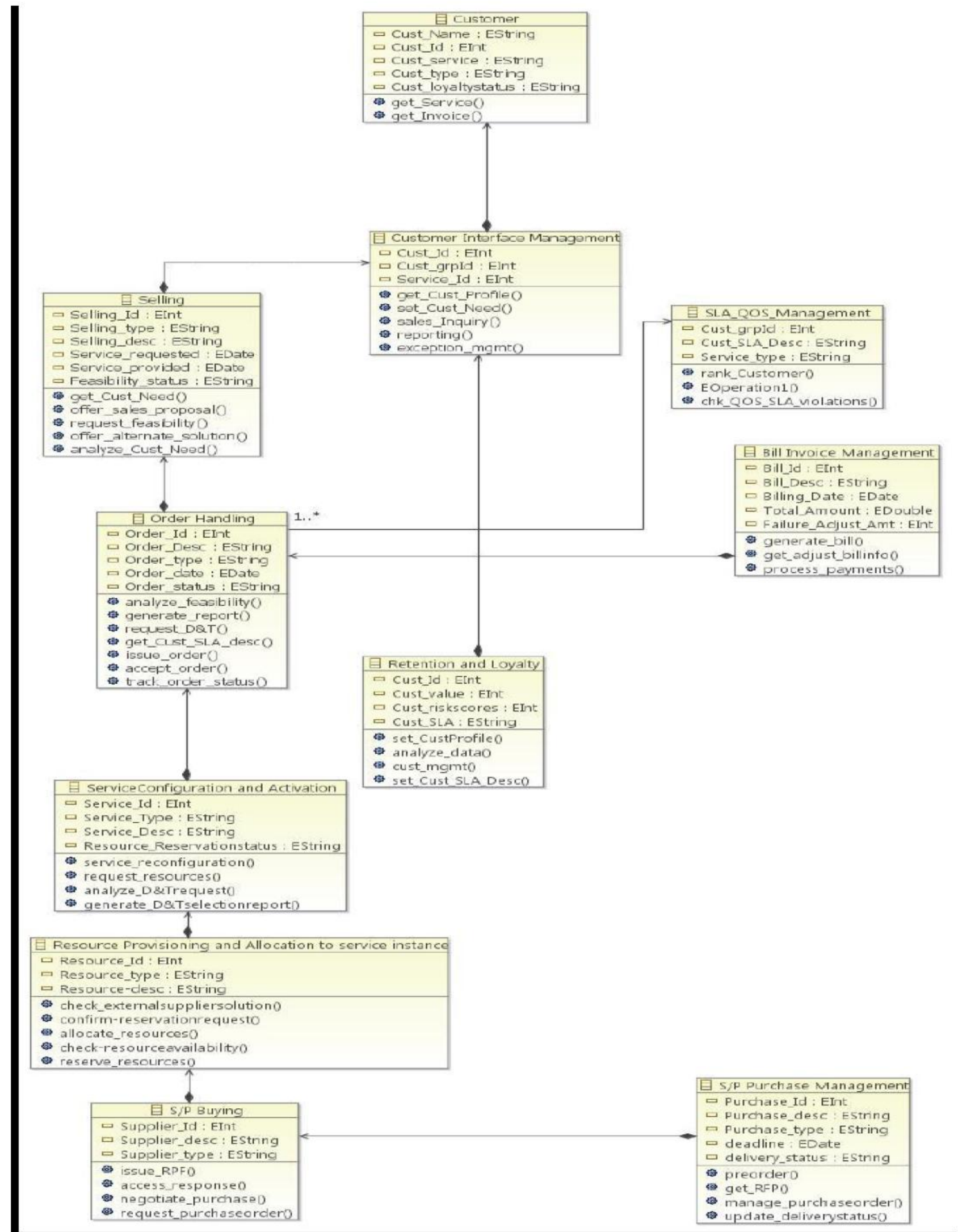

Fig. 1. : Ecore meta-meta model representation of eTOM Order Fulfillment Process 


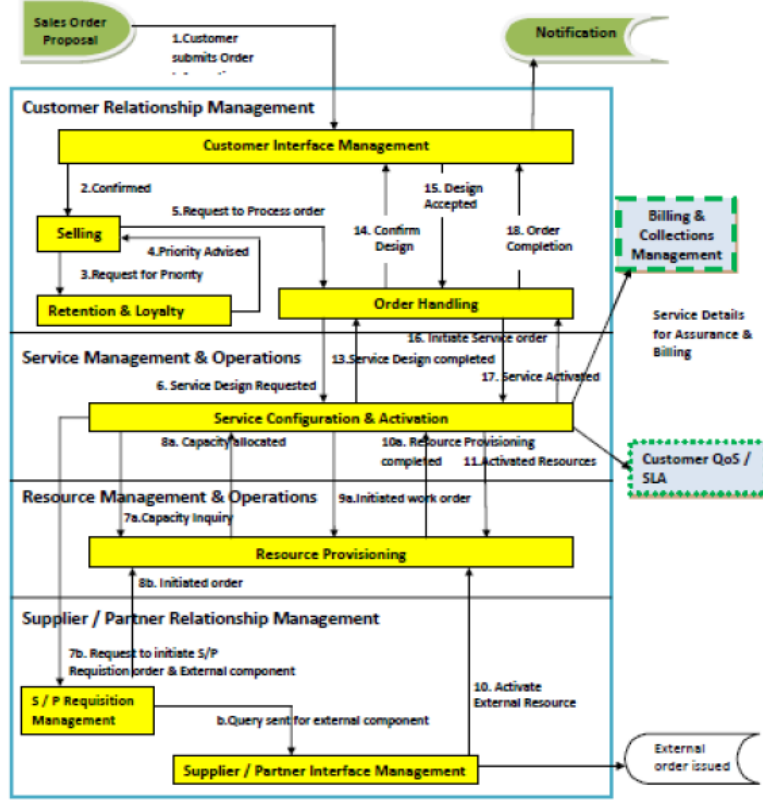

Fig 2 : Order Fulfillment End-to-End Process Flow in a cellular network Level 2 decomposition

\subsubsection{Case Scenario}

The customer submits a request for New Order Processing in the system [17] (not depicted in figure) and is given Sales Order Proposal (SOP) by the system [17]. SOP contain order information like product information ( Requested cellular services granted to new customer), General information (bandwidth, access etc.), Status information (cellular services activation time period) and other offer details (standardized or individual offers) provided by the Cellular service provider. This process flow deals with all activities through steps as shown in figure 2 [ 1 to 19] such as capturing customer order information, triggering the relevant services and its necessary resource provisioning process and finally handing over the order with confirm notification to the customer is explained as below :

The Process flow begins by capturing the customer order information routed through CIM to Selling process for the confirmation of order details (acquire customer data, authorize credit, determine order feasibility). Selling process send a request to Retention and Loyalty process to build customer insight for priority. Priority is then advised to Selling process and in turn it request Order Handling process to issue process order. Now, Order Handling process triggers the Service Configuration and Activation (SCA) process to provide service design solution (as per the product information) with specific service parameters (bandwidth, accessibility, connectivity) for all requested services.

Before SCA process activate the services, it check for internal resource availability through Resource Provisioning process and if supply is required it also initiates Supplier/ Partner Requisition Management process to verify the availability of services with other Cellular Service Provider (CSP) Network. However, there might be a reservation of some critical resources, depending on the CSP's policies and procedures. Once the required resources are allocated, SCA process triggers the Resource Provisioning (RP) process to initiate internal work order. The required resources are configured, implemented, tested and activated by RP process. To get the design confirmation from the customer, SCA passes the design solution suggested by the cellular service provider through Order Handling process. After service design is accepted, entire service portfolio will sent to Customer QoS / SLA Management and Billing Collections Management processes for Assurance and Billing vertical processes respectively. Finally, the customer order is completed and closed with notification message, sent to Customer. Then the Customer Satisfaction is validated.

Ecore meta-meta model representation is a model-driven software design, which is the simplied representation of Ecore class hierarchy. It is designed by Eclipse Modeling Framework (EMF) to map eTOM order Fulfillment end-to end process flow with Ecore object instances as shown in figure 1.

\section{CONCLUSION AND FUTURE WORKS}

Next Generation OSS's Structural view was studied with its eTOM Business Process Framework, defined by TMF. Also eTOM and its associated mapping with other standard framework bodies such as Zachman, COBIT, TOGAF and ITIL frameworks has been compared and discussed in an elaborate manner. The Case Study, designed for the cellular network of End-to-End Order Processing Flow illustrated the necessities of the Standard Business Process Frameworks. The comparison of eTOM with various business process frameworks shows that they are compatible, complementary and mutually supportive.

In future we are planning for the creation of Negotiation Service Component in service stratum of NGN architecture using different auction protocols, required among the NGN providers in order to achieve the better user Quality of Service.

\section{REFERENCES}

[1] General principles and general reference model for next generation networks, ITU-T Y.2011

[2] Functional requirements and architecture of the NGN, ITU-T Y2012

[3] The Open Group Architecture Framework(TOGAF), Version 8 "Enterprise Edition", Document no: 1911, December 2002.

[4] B.Y. Chang, S. Ko, D. Hong, Introduction to NGOSS and Telecommunication Network Operations Management with eTOM (Published Conference Proceedings style), Proc.13th Annu. Conf. KIIE and KORMS, 2007.

[5] TM Forum: Enhanced Telecom Operations Map (eTOM), ITU-T Y, 2012Tavel, P. 2007 Modeling and Simulation Design. AK Peters Ltd.

[6] TM Forum: Enhanced Telecom Operations Map (eTOM). GB 921D, ETSI ES 282001 version 1.1.1Forman, G. 2003

[7] B. R. MohanRam, S. Balasubramanian, Automating Business Processes of Telecom Service Providers Using BPM and Web Services for NGOSS, White Paper InfoSys, 2003.

[8] B. Akhgar, M. G. Juan Munoz, A. L. Jose Lopez, J. Siddiqi, H. Nazaraf hah, Business Oriented OSS for NGN.

[9] S. Sahibudin, M. Sharifi, and M. Ayat, Combining ITIL, COBIT and ISO/IEC 27002 in Order to Design a Comprehensive IT Framework in Organizations, 2nd 
Asia International Conference on Modeling Simulation (AICMS 2008), pp. 749-753, May 2008.

[10] Stan Loche, The Zachman Enterprise Architecture, Metadata Systems Software, 2003.

[11] Service Creation and Provisioning in NGN, Recommendations / RFC.Rec.ITU-T-Y.2201 (09/2009)

[12] C. T. Betz, Ongoing confusion of process and function, October 2011.

[13] T. Pelvyak, V. Sahin, Next Generation telecom networks, services and management, Third - CA technologies, October 2010.
[14] R. E. Stroud, Using COBIT and ITIL , 2nd Asia International Conference on Modeling Simulation (AICMS 2008), pp. 749-753, May 2008.

[15] B. Y. Chang, Business Process Management of telecom companies: Fulfillment and Operations Support and readiness cases, International Journal of Future generation Communication and Networking, Volume 4, No: 3, September 2011.

[16] E. Ronco, The enhanced Telecom Operation Map (eTOM) Businees Process Framework , Information and Communication Service Provider(ICSP), Volume 2, No:4,June 2002

[17] Introduction to eTOM , CISCO Technologies. 